\title{
EVALUATION OF THE PLANTING SCHEDULE OF SOYABEAN/CASSAVA INTERCROP SYSTEMS FOR OPTIMUM YIELDS IN THE GUINEA SAVANNA OF NIGERIA
}

\author{
I.A. YUSUF *E.A AIYELARI, *H. TIJANI ENIOLA AND *E .O. OYEKANMI.
}

National Cereals Research Institute, P.M.B. 8, Bida, Niger State, Nigeria. E-mail;iayusuf22@yahoo.com: 08078185711.Agronomy Department *University Of Ibadan, Ibadan, Nigeria

\begin{abstract}
Seven soyabean/cassava intercrop planting schedules were evaluated in a field trial at the National Cereal Research Institute, Badeggi during the 2005 and 2006 cropping seasons with a view to determining the planting schedule that will result in optimum yields of the component crops. Experimental design was randomized complete block with three replicates. The soyabean variety TGX 1019 2EB was intercropped with cassava variety 92/0427 using the following planting schedules:- (1) Cassava planted at 28 Days Before Planting Soyabean (28 DBPS) (2) Cassava planted at 14 Days Before Planting Soyabean (14 DBPS) (3) Soyabean /Cassava Planted Same Day (PSD) (4) Cassava planted at 14 Days After plating Soyabean (14 DAPS) (5) Cassava planted at 28 Days After Planting Soyabean (28 DAPS) (6) Sole cassava (planted on the $30^{\text {th }}$ of June; recommended planting time in this agro-ecological zone) (7) sole soyabean (planted on the $28^{\text {th }}$ of July; recommended planting time in this agro-ecological zone. Results obtained indicated that the planting of cassava at 28 Days Before Planting Soyabean (i.e. soy + cas 28 DBPS) resulted in the highest cassava yields of 41,700 and $42,182 \mathrm{~kg} / \mathrm{ha}$ in 2005 and 2006 respectively. These yields were significantly higher $(P=0.05)$ than the cassava yields obtained at the other intercrop treatments in both years. This treatment also resulted in the highest gross yields of the component crops as indicated by the LER in both years.
\end{abstract}

KEY WORDS: Cassava, Soyabean, Planting Schedule, Gross Yields.

\section{INTRODUCTION}

Intercropping has been traditionally favoured by peasant farmers as it reduces the likelihood of total crop failure (Balasubramanian and Sekayarige, 1991). Okoli et al. (1996) reported that the total dry matter yield was higher under intercropping than under monocropping systems. In Malawi where small holders farmers intercrop maize and pigeon pea, it was demonstrated that intercropping long duration pigeon pea varieties without reducing the normal maize population, resulted in minimal yield reduction of the associated maize in addition to the benefits of pigeon pea yield of grain and fuel wood (Sakala, 1994). Yusuf et al. (2004) report that the intercropping of sorghum seedlings with soyabean on soyabean planting day resulted in optimum yields of the component crops, as compared to intercropping the sorghum seedlings with soyabean at 14 and 28 Days After Planting Soyabean (DAPS). Adeniyan (2007) reported that under intercropping system that consisted of soyabean as one of the components, biological weed control was very effective through the smoothering effects that the soyabean had on weeds. Mudita et al. (2008) reported that SC513, a semierectophile maize variety intercropped with a determinate soyabean storm cultivar gave optimum yields of the component crops in Zimbabwe. The efficiency of intercropping systems is most often assessed in terms of their land equivalent ratio (LER). LER is indicative of the competitive relationships between species. If LER is less than 1 , there is mutual inhibition; if it is equal to 1 , there is mutual cooperation, when it is greater than 1 , there is mutual compensation; this suggests that intercropping is more productive than sole cropping (Blade et al ., 1997). Nigeria is the world largest producer of cassava with an annual production of about 333 million tons (NRCRI, 1998). Many new cassava varieties have been developed at the International Institute of Tropical Agriculture (IITA), Ibadan, Nigeria and National Root Crops Research Institute, Umudike, Nigeria (NRCRI, 1998). There is however, no information on the appropriate planting schedule required for intercropping these new cassava varieties with equally new soyabean varieties, for optimum yields of the component crops. Thus, 
the need to conduct an experiment to ascertain the appropriate planting schedule required for optimum yields of the component crops.

\section{MATERIALS AND METHODS}

A field experiment was conducted at the National Cereals Research Institute in Badeggi (Guinea Savanna agro-ecology) in 2005 and 2006. Composite soil samples were obtained with a soil auger into a plastic bucket and properly mixed. It was air-dried at room temperature and passed through a $2 \mathrm{~mm}$ sieve before it was taken to the laboratory for analysis. Soil total $\mathrm{N}$ was determined by the Kjedahl method, available P by the Bray $\mathrm{P}_{1}$ method, exchangeable $\mathrm{K}$ by the use of flame photometer. The soil $\mathrm{pH}$ was measured in a soil water ratio of $1: 2$ with a glass electrode and $\mathrm{pH}$ meter. Soil physical properties were determined by the hydrometer method.

Experimental design was randomized complete block $(\mathrm{RCB})$ with three replicates. The experiment was planted on ridges on a $14 \times 24 \mathrm{~m}$ land area. The gross plot $(4 \times 3 \mathrm{~m})$ consisted of 4 ridges spaced $0.75 \mathrm{~m}$ apart, while the net plot $(3 \times 1.5 \mathrm{~m})$ consisted of the two central ridges of each plot. Soyabean seeds were drilled on the crest of the ridge at a spacing of $0.05 \mathrm{~m}$ within the ridge and $0.75 \mathrm{~m}$ between the ride to give a plant population of 266,666 plants per ha. Cassava stems were planted at a spacing of $1.0 \mathrm{~m}$ within the ridge and $0.75 \mathrm{~m}$ between the ridge to give a plant population of 13,333 plants per ha. Soyabean variety TGX 1019-2EB, was planted on the $28^{\text {th }}$ of July in all the treatments and intercropped with cassava variety $92 / 0427$, using the following planting schedules:- (1) cassava planted at 28 Days Before Planting Soyabean (28 DBPS) i.e. $30^{\text {th }}$ of June in 2005 and 2006 respectively. (2). Cassava planted at 14 DBPS (i.e. $14^{\text {th }}$ of July in 2005 and 2006 respectively. (3) Cassava and soyabean Planted on the Same Day (PSD) i.e. $28^{\text {th }}$ of July, in 2005 and 2006 respectively. (4). Cassava planted at 14 Days After Planting Soyabean (14 DAPS) i.e. $11^{\text {th }}$ of August in 2005 and 2006 respectively. (5) Cassava planted at 28 DAPS (i.e. the $25^{\text {th }}$ of August in 2005 and 2006 respectively. (6) Sole cassava: planted on the $30^{\text {th }}$ of June in 2005 and 2006 respectively. (7) Sole soyabean planted on the $28^{\text {th }}$ of July in 2005 and 2006 respectively. Fertilizer NPK (15-15-15) was band applied at the rate of $30 \mathrm{~kg} / \mathrm{ha}$ to the crops in each ridge at 2 weeks after planting soyabean. Weed control was achieved by two hoe weedings at 3 and 6 weeks after planting.

Data collected from 30 soyabean plants and 9 cassava plants obtained at random per treatment were plant height, branches per plant, pods per plant, stover and grain yields, for soyabean and plant height, branches per plant, establishment count, fresh leaf and tuber yields for cassava. Data were analyzed using the analysis of variance and significant means separated by Duncan's Multiple Range Test (DMRT).

\section{RESULTS AND DISCUSSION}

Analyzed soil test result of the composite soil sample, presented in Table 1, indicated that the soil was acidic with a pH of about 5 to 5.7. The N P K Ca Mg and ECEC contents were below their critical levels and the soil texture sandy. 


\section{Planting Schedule of Soybean/Cassava intercrop}

Table 1: The chemical and physical properties of the composite soil samples obtained from the experimental site.

\begin{tabular}{|c|c|c|c|}
\hline Soil properties & 2005 & Year of Collection & 2006 \\
\hline $\mathrm{pH}\left(\mathrm{H}_{2} \mathrm{O}\right)$ & 5.70 & & 5.00 \\
\hline $\mathrm{TN}(\mathrm{g} / \mathrm{kg})$ & 0.40 & & 0.30 \\
\hline Av. P (mg/kg) & 2.90 & & 2.35 \\
\hline $\mathrm{Ca}\left(\mathrm{cmol} \mathrm{kg}^{1}\right)$ & 1.24 & & 0.34 \\
\hline $\mathrm{Mg}$ “ & 1.23 & & 0.08 \\
\hline K “ & 0.08 & & 0.05 \\
\hline $\mathrm{Na}$ “ & 0.04 & & 0.02 \\
\hline $\begin{array}{l}\text { Total } \\
\text { acidity “ }\end{array}$ & 0.02 & & 0.02 \\
\hline ECEC “ & 2.61 & & 1.01 \\
\hline Sand $\mathrm{g} / \mathrm{kg}$ & 875.8 & & 876.8 \\
\hline Silt " " & 112.2 & & 111.1 \\
\hline Clay “" & 12.0 & & 13.1 \\
\hline Textural class & Sandy & & Sandy \\
\hline
\end{tabular}

Soyabean yield components obtained in 2005 indicated that plant height, branches and pods per plant, stover yields were not significantly different at the various intercrop treatments evaluated (Table 2). In 2006, soyabean plant height and branches per plant were also not significantly different at the various intercrop treatments evaluated. This was probably due to the fact that cassava has an initial slow growth, which helped to delay the commencement of competition for light, water and nutrients between the component crops. Furthermore, soyabean is a $\mathrm{C}_{3}$ plant and as such was less detrimentally affected by shading from cassava plant. In 2005, there were no significant differences in soyabean yields at most of the intercrop and sole soyabean treatments evaluated. Similar trends were obtained in 2006. The trends observed in both years were also due to the fact that cassava has an initial slow growth. IITA (1990) reported that cassava has initial slow growth in the first three months of its growth. The soyabean plants therefore did not experience any serious competition in most of the intercrop treatments in the first three months of intercrop.

Tables 2: Soyabean yield components and yields

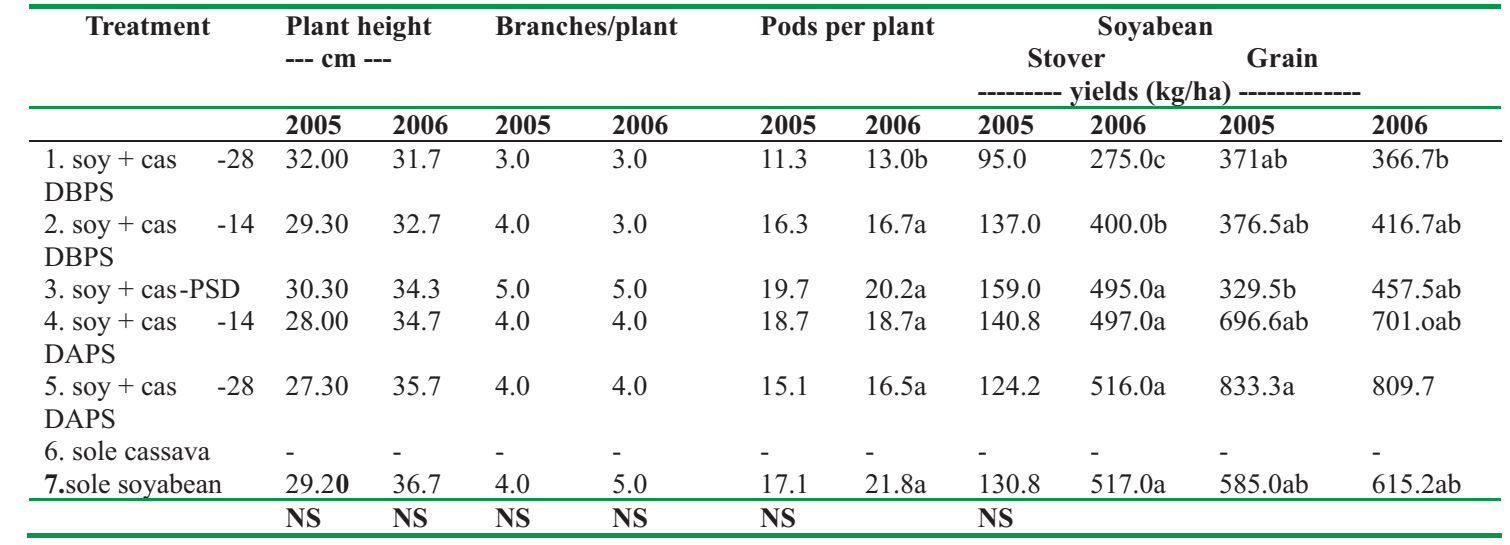

Means with same letter (s) within the same column are not significantly different at $P \leq 0.05$ 


\section{I.A. Yusuf E.A Aiyelari, H. Tijani Eniola and E.O. Oyekanmi.}

(DMRT)Cassava plant height, branches per plant, establishment count, fresh leaf weight and yields were generally higher when cassava was planted at 28 Days Before Planting Soyabean (28 DBPS) as compared to the other intercrop treatments (Tables 3 ). This was probably due to the fact that the cassava that was planted at 28 DBPS had a longer time to carry out photosynthesis during the raining season when compared to other intercrop treatments in which cassava was planted at later dates. In addition,

\section{Table 3: Cassava yield components and yields}

\begin{tabular}{|c|c|c|c|c|c|c|c|c|c|c|c|}
\hline \multirow{2}{*}{\multicolumn{2}{|c|}{ Treatment }} & \multicolumn{2}{|c|}{$\begin{array}{l}\text { Plant height } \\
---\mathrm{cm} \text {--- }\end{array}$} & \multicolumn{2}{|c|}{ Branches/plant } & \multicolumn{2}{|c|}{$\begin{array}{c}\text { Establishment } \\
\text { count } \\
\%\end{array}$} & \multicolumn{2}{|c|}{$\begin{array}{c}\text { Fresh leaf } \\
\text { weight }\end{array}$} & \multicolumn{2}{|c|}{ Cassava yields } \\
\hline & & 2005 & 2006 & 2005 & 2006 & 2005 & 2006 & 2005 & 2006 & 2005 & 2006 \\
\hline $\begin{array}{l}\text { 1. soy + cas } \\
28 \text { DBPS }\end{array}$ & - & $71.1 \mathrm{a}$ & $71.6 \mathrm{a}$ & $2.3 \mathrm{a}$ & $2.5 \mathrm{a}$ & $100.0 \mathrm{a}$ & $100.0 \mathrm{a}$ & $6000.0 \mathrm{a}$ & $5790.0 \mathrm{a}$ & $41,700.0 \mathrm{a}$ & $42,182.0 \mathrm{a}$ \\
\hline $\begin{array}{l}\text { 2. soy + cas } \\
14 \mathrm{DBPS}\end{array}$ & - & $55.7 \mathrm{bc}$ & $4.4 \mathrm{~b}$ & $2.0 \mathrm{a}$ & $2.1 \mathrm{ab}$ & $83.3 \mathrm{ab}$ & $83.3 \mathrm{a}$ & $4500.0 \mathrm{ab}$ & $4660.0 \mathrm{a}$ & $33500.0 \mathrm{~b}$ & $35,635.0 \mathrm{~b}$ \\
\hline $\begin{array}{l}\text { 3. soy + cas } \\
\text { PSD }\end{array}$ & - & $57.4 \mathrm{bc}$ & $56.2 b$ & $1.6 \mathrm{a}$ & $1.5 \mathrm{bc}$ & $66.7 \mathrm{~b}$ & $83.3 \mathrm{a}$ & $4500.0 \mathrm{ab}$ & $4930.0 \mathrm{a}$ & $26133.3 \mathrm{c}$ & $21,815.0 \mathrm{c}$ \\
\hline $\begin{array}{l}\text { 4. soy + cas } \\
14 \text { DAPS }\end{array}$ & - & $45.6 \mathrm{c}$ & $42.1 \mathrm{c}$ & $1.5 \mathrm{a}$ & $1.2 \mathrm{c}$ & $50.0 \mathrm{c}$ & $56.7 \mathrm{~b}$ & $2000.0 \mathrm{bc}$ & $2500.0 \mathrm{~b}$ & $10766.7 d$ & $10,617.0 \mathrm{~d}$ \\
\hline $\begin{array}{l}\text { 5. soy + cas } \\
28 \text { DAPS }\end{array}$ & - & $31.6 \mathrm{~d}$ & $30.6 \mathrm{~d}$ & $1.6 \mathrm{a}$ & $1.0 \mathrm{c}$ & $56.3 \mathrm{c}$ & $58.3 \mathrm{~b}$ & $1000.0 \mathrm{c}$ & $1600.0 \mathrm{a}$ & $3600.0 \mathrm{e}$ & $4,729.0 \mathrm{e}$ \\
\hline 6.sole cassava & & $66.9 \mathrm{~b}$ & $70.4 \mathrm{a}$ & $2.3 \mathrm{a}$ & $2.5 \mathrm{a}$ & $100.0 \mathrm{a}$ & $100.0 \mathrm{a}$ & $5800.0 \mathrm{a}$ & $6130.0 \mathrm{a}$ & $41,633.3 \mathrm{a}$ & $41,500.0 \mathrm{a}$ \\
\hline $\begin{array}{l}\text { 7.sole } \\
\text { soyabean }\end{array}$ & & -- & --- & --- & --- & --- & --- & --- & --- & --- & --- \\
\hline
\end{tabular}

Means with the same letter (s) within the same column are not significantly different at $P \leq 0.05$

(DMRT) competition between the component crops did not commence until about 28 days or more when soyabean was planted. The enhanced cassava establishment obtained when it was planted at 28 Days Before Planting Soyabean, was probably also responsible for the significantly higher cassava yields $(\mathrm{P}=0.05)$ obtained in this treatment, as compared to the other treatments in both years.

The land equivalent ratios (LER) computed indicated that the planting of cassava at 28 DBPS gave the highest LER of 1.63 in both years. (Table 4)

Table 4: Effects of intercropping cassava cuttings with soyabean on the productivity of the component crops

\begin{tabular}{|c|c|c|}
\hline Treatment & Land & Ratios (LER) \\
\hline & 2005 & 2006 \\
\hline 1. Soy + Cas -28 DBPS & 1.63 & 1.63 \\
\hline 2. Soy + Cas -14 DBPS & 1.44 & 1.44 \\
\hline 3. Soy + Cas - PSD & 1.30 & 1.19 \\
\hline 4. Soy + Cas - 14 DAPS & 1.45 & 1.45 \\
\hline 5. Soy + Cas -28 DAPS & 1.51 & 1.51 \\
\hline 6. Sole Cassava & --- & --- \\
\hline 7. Sole Soyabean & --- & --- \\
\hline
\end{tabular}

This suggests that this planting schedule will result in higher gross yields of the component crops than any of the other intercrop treatments.

Niger Agric. J. 40 No. 1 (2009): 145 - 149

$-148-$ 


\section{Planting Schedule of Soybean/Cassava intercrop}

\section{CONCLUSION}

The planting of cassava at 28 Days Before Planting Soyabean resulted in the highest gross yields of the component crops in both years. The highest cassava yield of 41,700 and $42,182 \mathrm{~kg} / \mathrm{ha}$ were obtained in 2005 and 2006 respectively, from this treatment. In addition, soyabean yield was not depressed significantly $(\mathrm{P}>$ 0.05 .) at this treatment in the year 2005. These facts were further corroborated by the highest land equivalent ratios (LER) of 1.630 and 1.631, which were obtained from this treatment in 2005 and 2006 respectively.

\section{REFERENCES}

Adeniyan, O. N. and Ayoola, O.T. (2007). Evaluation of four improved soyabean varieties under different planting dates in relayed cropping system with maize under soyabean/maize/cassava intercrop. WWW. academic journals. Org/AJB/PDF/pdf 2007/ 4 oct. /Adeniyan $\% 20$ and $\% 20$

Ayoola. Pdf. Cached page PDF file.

Balasubramanian, V. and L. Sekayarige (1991). Area harvest quivalency ratio for measuring efficiency of multi season intercropping. IITA Research 1(2): 16-19.

Blade, S.F., V.R. Shetty, T. Terao and B.B. Singh (1997) : Recent development in cowpea cropping systems research. In singh B.B., R. MohanRaj, K.E. Dashiell and L.E.N. Jackai (eds) Advances in Cowpea Research. Co-publication by IITA. \& JIRCAS, Ibadan

IITA (1990) Cassava in tropical Africa. A reference manual. United Nation Children Fund (UNICEF) 196p.

Mudita, I. I., C. Chiduza, S.J. Richardson-Kageler and F.S.Murungu (2008). Performance of maize (Zea mays L.) and soyabean (Glycine max (L.) Merril) cultivars of different growth habits in intercrop in subhumid environments of Zimbabwe. Journal of Agronomy 7:229-236.

NRCRI (1998) Report on the implementation of the Nationally Coordinated Research Project (NCRP) on cassava and yam. (Jan - Sept 1997) and work plan for 1998. 53p.

Okoli, O.O., M.A. Hassan, A.F.K. Kassiedu and B.A. Aserel (1996). Effects of planting dates and growth habit of cassava and cowpea on their yield and compatibility. Tropical Agriculture 73(3): 169 - 174.

Sakala, W.D. 1994. Crop Management Intervention in Traditional maize pigeon pea intercropping system in Malawi. M. Sc. Thesis Bunda College University of Malawi.

Yusuf, I.A., E.A. Aiyelari, A.A Idowu and E.D. Oyekanmi (2004) Evaluation of the planting schedule of soyabean / sorghum intercrop systems for optimum yields in the Guinea Savanna Zone of Nigeria. Nigerian Agriculture Journal. 35: 13 - 21 